\title{
The Gender of Water and the Pleasure of Alienation: A Critical Analysis of Visiting Hoover Dam
}

\author{
RICHARD A. ROGERS
}

School of Communication, Northern Arizona University

\section{JULIE KALIL SCHUTTEN}

Department of Communication, University of Utah

\begin{abstract}
Hoover Dam, located on the Arizona-Nevada border and damming the Colorado River, is a well-known and often-visited place. The meanings people assign to such a structure articulate key environmental, economic and technological ideologies. An exploration of those meanings is important for understanding the forces that shape public perception and environmental policy. Specifically, this essay examines the official rhetoric of Hoover Dam from an ecofeminist perspective. Through a critical reading of the educational displays, films, plaques and other texts as well as the physical structure of the dam itself, three rhetorical strategies used in the dam's official presentation are identified. First, the Bureau of Reclamation presents the Colorado River as a chaotic, feminine entity in need of masculine control. Second, the river's rhetorical status as an Other encourages audiences to identify with the subject position of nature's master and thereby participate in the pleasures such an identity offers. Third, the Bureau uses the prevalent "common sense" of Native Americans as environmentally sensitive in combination with an "historical" Native American voice to establish the dam as both environmentally sound and a logical step in humanity's progress toward economic development and dominion over nature.
\end{abstract}

Hoover Dam is a preeminent symbol of the transformation of the North American West through the control of water. While subsequently dwarfed by projects that are physically larger, more costly, and more challenging in terms of politics

An earlier version of this paper was presented at the Western States Communication Association convention, Rhetoric and Public Address Division, Vancouver, B.C., February 1999.

Address correspondence to Richard A. Rogers, School of Communication, Box 5619, Northern Arizona University, Flagstaff, AZ 86011. E-mail: richard.rogers@nau.edu 
or engineering, the Hoover Dam can offer great insight into the ideological articulations involved in maintaining the "common sense" of (post)modern environmental industrialization. Situated on the border between Nevada and Arizona and damming the Colorado River, Hoover Dam (also known as Boulder Dam) was completed in 1935 and created the giant reservoir and water park known as Lake Mead. Because of Hoover Dam's close proximity to Las Vegas, its positioning on the main route between Las Vegas and the Grand Canyon, and its status as the first large dam on the Colorado, it is a well-known and often-visited place.

In his review of recent books on the history of water development in the twentieth-century United States, Steinberg (1993) argues that such works are pervaded by an implicitly traditional use of "power" as an inherently negative, repressive, and constraining force. He suggests that an understanding of power, discourse, and truth informed by the work of Foucault needs to be brought to the study of water politics and practice. Power is a productive as well as constraining force intimately linked to epistemology, ethics, and discourse. Steinberg argues that this view allows us to ask some new questions about water management projects: "How is it that the structure and design of large dams such as Hoover and Glen Canyon have come to be seen as rational? Why is it so easy to be seduced by their grandeur and implacable logic?" (p. 408).

More specifically, Steinberg (1993) suggests that the dominant view of water is as a resource, something to be

managed, administered, controlled, saved, and spent. And the destiny of water in modern American culture has to be tied to precisely this understanding. ... It remains then to explore the history of truth and water in the $20^{\text {th }}$ century. How has power functioned to render water as a resource? How is it that this view of water has counted as true? What role has power played in limiting the range of possible meanings ascribed to water? Why has the control of this resource . . . had such overwhelming appeal in $20^{\text {th }}$-century America? (p. 408)

This essay works to address Steinberg's questions by examining the discourses presented to visitors of Hoover Dam.

\section{Rhetorical Significance of Hoover Dam}

Hoover Dam was built in the midst of the Great Depression, from 1931 to 1935, a fact which enhances its symbolism as a triumph of "man" over nature and of the United States over its hardships. It was by far the largest dam ever built when it was completed and until 1968 remained the tallest dam in the United States (McCully, 1996). It serves to regulate the flow of the Colorado, provide water for agriculture and municipal use, and generate electricity for California, Nevada, and Arizona. More than seven hundred thousand people each year take a paid 
tour of the dam and many more walk and drive across it when passing between Arizona and Nevada on U.S. Highway 93; since their beginning in 1937, more than thirty-one million people have taken a tour of the dam. Lake Mead is also a significant attraction. As the largest artificial lake in the United States that also sits amid some of the hottest and driest geography in the West, its five hundred miles of shoreline attracts more than nine million visitors a year (all statistics from U.S. Department of Interior, Bureau of Reclamation, 1998).

As the Bureau of Reclamation's Hoover Dam Web site and tour guides proudly proclaim, the dam has been rated by the American Society of Civil Engineers as one of America's "Seven Modern Civil Engineering Wonders" as recently as 1994 (almost sixty years after its completion). In addition, Hoover Dam continues to be held up as a preeminent symbol of U.S. American power and progress. A 1999 article in Business Week lists Hoover Dam, along with twelve other devices such as the hydrogen bomb, as an outstanding example of "men . . . trying to tame power," something formerly "the province of the gods" (Raeburn etal., 1999, p. 52). A 1997 special issue of Time magazine also cited the architecture of the dam as one of nine examples of "The Beauty of Big" in U.S. American art: "It asserts the power of technology and predicts a limitless reign over the forces of nature" (Hughes, 1997). As McCully (1996) writes in Silenced Rivers, "Massive dams are much more than simply machines to generate electricity and store water. They are concrete, rock and earth expressions of the dominant ideology of the technological age: icons of economic development and scientific progress to match nuclear bombs and cars" (pp. 2-3).

The construction of Hoover Dam was controversial in the 1920s and 1930s because of concerns over its technical feasibility and fiscal impact (Vilander, 1999). Other controversies include its name, which was finally settled in a 1947 act of Congress reinstating Hoover Dam (as opposed to Boulder Dam) as the official name. However, since the construction of Glen Canyon Dam in the early 1960s, environmental debates concerning the Colorado River ecosystem have been focused on that site upstream from the Grand Canyon, not Hoover Dam. According to the National Park Service (2001), "the controversy surrounding the construction of [Glen Canyon] dam is often cited as the beginning of the modern-day environmental movement." While environmentalists advocate for the decommissioning of some smaller dams in the western United States as well as Glen Canyon Dam and (further upstream on the Green River) Flaming Gorge Dam (Farmer, 1999), we have discovered no specific proposals to decommission Hoover Dam and drain Lake Mead. Within the current "regime of truth" (Foucault, 1980) regarding dams, water, nature, and progress, decommissioning Hoover Dam appears to remain in the realm of what Foucault (1970) describes as "the stark impossibility of thinking that" (p. xv). Therefore, one impetus for studying the contemporary texts of Hoover Dam is to explore how power and discourse constitute a "common sense" which both constrains what can be conceived (e.g., decommissioning Hoover Dam) and simultaneously enables the public's consent to environmental industrialization. 


\section{Scope and Approach}

This study is an analysis of the "official" texts of Hoover Dam likely to be encountered by visitors to the dam: written texts, photographs, videos, films, tours, and other artifacts at or near the dam site, with particular emphasis on the thirtyminute multi-media presentation offered to all paying visitors to the dam since 1998. We also engage in an analysis of the dam site itself - the dam, statues, and other fixed features - as additional "texts" which influence visitors' interpretations of the dam's meaning(s). ${ }^{1}$ The primary purpose of this analysis is to identify the central themes, narratives, and ideologies which the official interpreters of the dam offer to guide the sense-making of visitors. Our purpose is not merely to identify the themes present in these discourses, but also to determine how they might work to constrain resistant readings and promote the dominant ideologies which support the dam. In Steinberg's (1993) terms, how is it that the control of water-in this instance, by means of large dams-has come to have such appeal?

Specifically, we examine those texts encountered by visitors to the dam during our fieldwork in 1998 and 1999. One of our primary areas for analysis is how these texts constitute the "history" of Hoover Dam, the Colorado River, and the southwest United States. Guided by Berger's (1972) comment that "history always constitutes the relationship between a present and its past" (p. 11), we are interested in how the rhetorical shaping of "history" articulates with the power relationships implicated in Hoover Dam. ${ }^{2}$ What histories and relationships are obscured by the dam, and how are visitors motivated by the histories that are presented? How does this help to understand the appeal of water and, more to the point, its control?

The timing of our fieldwork raises another limitation to this study. Since September 11, 2001, tourism at Hoover Dam has undergone significant changes. For security reasons, large vehicles have been prohibited on the dam (which serves as a bridge for the highway) and automobiles move through security checkpoints before approaching the dam. In addition, tours inside the dam were halted for several months. Although tours have now resumed, they now take place almost entirely on the top of the dam, with only limited visitation allowed inside and at the bottom of the dam. Hoover Dam's symbolism has now been articulated further by its attachment to the discourses of "terrorism" and "homeland security." This has likely profoundly altered the rhetoric and experience of Hoover Dam, but again such changes are beyond the scope of this study.

\section{Common Sense}

The power of discourse to shape the possible can be understood in terms of Gramsci's (1971) concept of hegemony and the influence of "common sense." Critical theorists have demonstrated that one of the most powerful ways a social order is maintained is through controlling what it is possible to conceive (e.g., 
Williams, 1977). The meanings people assign to a structure such as Hoover Dam articulate key environmental, economic, and technological ideologies. Therefore, an exploration of those meanings is important for understanding the forces that shape public perception and environmental policy, such as those involved in the debate over the future of Glen Canyon Dam and the reservoir known as Lake Powell (upstream from Hoover Dam and the Grand Canyon). ${ }^{3}$

Following Steinberg's call for a more multidimensional analysis of power, we must not only look at how these discourses constrain the possibilities for thought and resistance, but also how discursive power operates to produce identities and pleasures. How do these creations of power help reproduce the dominant ideologies and their attendant economic, technological, and environmental systems? We believe that the ideas grounded in ecofeminist thought offer a unique opportunity to analyze the meanings of Hoover Dam as a construction of "mankind's" subordination of nature.

\section{Ecofeminism}

In broad terms, what we offer here is a close, critical reading of the texts facing visitors to Hoover Dam by placing them in the contexts of dominant ideologies regarding nature, resources, instrumental reasoning, and industrialization (cf. DeLuca, 1999). These contextualizing choices are not arbitrary, but rather are guided by those contexts referenced by the official texts themselves, as well as those required for the historicization appropriate for a critical project motivated by environmental concerns consistent with some of the major tenets of ecofeminism. Our selection of ecofeminism as a critical frame was motivated by our initial examination of the texts presented to visitors of the dam. The dominant themes and metaphors included economic productivity, the power of technology, nature as female, and the preindustrial practices of non-Western peoples. The use of gender and nature as frameworks of domination and alienation were especially visible surrounding the dam. These are precisely the core issues of ecofeminism, but more importantly ecofeminism provides a system for understanding the interconnections between these themes. Following Warren (1997), we believe that there are important relationships-historical, empirical, conceptual, political, and theoretical - between the domination of women and the domination of nature. Therefore, any understanding of environmental rhetoric which fails to see or capture these relationships is missing vital contextual clues about the interconnections between multiple forms of oppression.

At the core of ecofeminism is an understanding of the interconnections between the oppression of women and the destruction of nature. Through a series of intertwined binary oppositions, the plundering and "development" of nature is justified by its gendering as feminine and the oppression of women is justified by their closer ties to "nature." Both woman and nature become "other" to the "self" of "civilized man." "'Culture' (order) was the male domain, while 'Nature' 
(chaos) was conceived as female and included women as a caste, slaves, indigenous peoples, nonwhite races, and animals" (Birkeland, 1995, p. 443). Without dualism the competitive nature of the Western patriarchal mentality is nonsensical as it is essential for rationalizing (producing) a conquering mentality toward nature.

Within this dualistic and hierarchical structure, "there remains a tendency to deny dependency upon, distance oneself from, and control what patriarchy has deemed 'female' (natural) aspects of one's internal and external nature" (Birkeland, 1995, p. 443). This denial of dependence is a key factor in "othering" nature; according to Val Plumwood (1993),

The key exclusions and denials of dependency for dominant conceptions of reason in western culture include not only the feminine and nature, but all those human orders treated as nature and subject to denied dependency. Thus it is the identity of the master (rather than a masculine identity pure and simple) defined by these multiple exclusions which lies at the heart of western culture. This identity is expressed most strongly in the dominant conception of reason, and gives rise to a dualized structure of otherness and negation.... (p. 42)

Identifying nature as female articulates the dualistic negatives associated with femininity. Valued aspects of society are thus the antifeminine and follow the logic of domination inherent in Western thought. For example, the dualisms reason/emotion, human/nature, production/reproduction, rationality/animality, and civilized/primitive are all similarly gendered and link nature to what Western culture has termed the feminine.

Ecofeminism is not a singular ideology, theory, or method, but its many varieties can be understood as both an ontology-i.e., a political stance about the nature of the world - and as an epistemology-i.e., a critical method (Deegan \& Podeschi, 2001). While these two elements are undoubtedly interrelated, in this essay we use a method of critical analysis that can be loosely described as ecofeminist without necessarily opting into claims about the intrinsically feminine nature of nature and the harmonious and nonhierarchical essence of woman/ nature (cf. Stearney, 1994). Indeed, much ecofeminist critique borrows from the poststructuralist (and therefore antiessentialist) tendency to identify binary oppositions, contextualize those oppositions within the operation of oppressive and destructive social systems, and ultimately "deconstruct" the system's logic by identifying the fractures and indeterminacies both faced by the system and created by the system itself. In particular, the ecological principle of interconnectedness becomes central in ecofeminist projects, both as an ontological principle (a claim about the nature of life/existence) and as a means to undermine the concepts of separateness and control upon which the dominant, dualistic paradigms (patriarchal, scientific, technical) are based. In addition, ecofeminist critique is 
valuable insofar as a central principle is the interconnected structure of the oppression suffered by women, children, people of color, homosexuals, and nonhuman nature. Understanding the particular operation of these binary structures in the rhetoric at Hoover Dam can assist with answering Steinberg's questions about the construction of water within the current regimes of truth as well as understanding how the discourses of Hoover Dam constitute identities based on exclusionary (dualistic) identities and pleasures.

\section{Reading Hoover Dam}

As we drive toward Hoover Dam the radio states that temperatures on the Colorado River are predicted to meet or exceed all established records-over 120 degrees (Fahrenheit) in places. When we arrive at the dam around half past one in the afternoon, there are a lot of people milling around outside on the concrete structure despite the incredible heat. We enter the visitors center and purchase the eight dollar tickets which grant us a thirty-five-minute standard dam tour as well as a half-hour multimedia presentation and all the exhibits about the dam and the region. Without this ticket, access to many areas, including most of the exhibits and the observation deck, is denied. Put another way, the ticket is necessary for entrance into air-conditioned spaces. Our guided tour starts in forty-five minutes, giving us just enough time to watch the half-hour multimedia presentation.

\section{Water, the Magic Elixir}

We sit in the first row of a traditional theater space-rows of seats curved to maximize the view of the main screen. The theater can hold over four hundred people. The first part of the presentation focuses on water, the second on the history of the region, and the third on the building of Hoover Dam. Between each segment, the entire seating section of the theater rotates to face a different set of displays. The first segment of the program utilizes two four-by-four grids of sixteen small television screens with two larger screens at the outer edges. Images "flow" across the interlinked screens, sometimes utilizing two grids of sixteen screens to create two composite screens, sometimes using all thirty-two together, often with the same image presented on the two larger side screens. The second segment presents a map of the Southwest and uses various other media: television screens, life-size three-dimensional displays of settlers, and projections onto a seethrough screen. The third segment uses one large screen reminiscent of a movie theater. Throughout, music is used to indicate appropriate emotional responses (awe, joy, fear) as well as to invoke the Native American heritage of the region.

The first segment focuses on water, leading viewers to worship in awe the centrality of water to human life in general and particularly in the Southwest. With light, uplifting music and images of clear, clean, abundant water we are convinced by repetition: 
Water: the vital fluid of life, the magic elixir that distinguishes our world from others in the universe.

Water: the substance that quenches our thirst.

Water: it governs our bodily climate, cleanses and comforts us.

Water: it nurtures the earth to feed us.

Water: it refreshes our spirit and stimulates our imagination. (U.S.

Department of the Interior, 1998)

Several elements of this first segment are important. First, the water we are shown is clean and clear or blue. We see water in swimming pools and fountains, water rushing over fresh vegetables, water splashing over a dog being washed, and water teeming with brightly-colored tropical fish. With the possible exception of the scenes with tropical fish, we are not shown water in its natural states or native contexts. The Colorado and other rivers are "dirty"that is, filled with sediment ("Colorado" literally means "reddish colored"). But also, in implicit contrast to the images shown in the Hoover presentation, natural rivers are "dirty" in the moral sense of being impure (cyclical and fluid instead of linear and predictable, wild instead of productive). The Colorado has been, materially, turned into a river with (relatively) cool, clear, blue water-devoid of silt, which is now building up behind dams such as Glen Canyon and Hoover (Pearce, 1991). The symbolic ideal we are shown on the screen has been made real. The plants, animals, ecosystems, and ways of life dependent on the "dirty" and free-flowing Colorado are erased almost immediately as this presentation begins. Second, these images define water's value in relation to human beings_-providing food, fun, and aesthetic enjoyment. This is particularly ironic in light of the next verbal statement: "Water ensures the vitality of every animal and plant that comprises the complex web of life to which we are inexorably bound." This "web of life" seems to center around human beings, with plants and animals presented only in terms of their use by humans. ${ }^{4}$

The only hint of concern in this first segment comes at the end. The adoration of water falters as the music turns ominous and the narrator transitions to the second segment:

Nowhere in the North American continent is the significance of water more apparent than in the southwestern United States. It is the omnipresent issue of water-its scarcity and capriciousness-which is the subject and the substance of life in this arid desert environment. (U.S. Department of the Interior, 1998)

Here, awe and joy turns to concern as we are told that water can be both limited and unpredictable. 


\section{Nature as Inhospitable}

The second segment focuses on the history of the region prior to the building of Hoover Dam and forms the core of an argument for the necessity of the dam based on the twin ideas of water's "scarcity and capriciousness." As the theater seats rotate, the music takes on a stereotypically "Native American" connotation and the primary image is a large map of the lower Colorado River basin: Colorado, Utah, Nevada, California, Arizona, and New Mexico. The map strives to appear old, as if on yellowed parchment, yet the cities labeled (Las Vegas, Flagstaff, Sedona, Moab, and Grand Junction) have more contemporary connotations, seemingly chosen not for their historical significance in terms of population or regional importance but for their association with tourism.

With images of the desert Southwest appearing on small monitors behind the translucent map, the narrator begins by dwelling on the beauty of the area. This emphasis lasts only briefly and soon we are encouraged to understand the Southwest in terms of heat and the sun, which throws the landscape into

blinding focus, driving animals and human alike to seek shelter. Whether by instinct or reason, this response to the harsh climate captures in an instant the character of this vast terrain. Parched by the insistent sunlight, shivering in its absence, and almost continually devoid of surface water, much of the 790,000 square miles of the United States we call the Southwest is inhospitable. (U.S. Department of the Interior, 1998)

But there is hope. In one of the few positive mentions of the Colorado River during the presentation, we are told the Colorado is an "artery of life" without which "the development and survival of human society would be impossible" in the Southwest.

This positive view of the river turns quickly, however, into the Bureau of Reclamation's dominant view of the river (already introduced with the earlier description of water as "capricious"): "The Colorado—-dangerous in flood, stingy in drought, erratic in mood and timing - but nevertheless the purveyor of life to all who would befriend her." In addition to the use of female pronouns to refer to the river, this comment is consistent with deeply-rooted, gendered dualisms in dominant Western ideologies. Women, being more grounded in their "natural" (as opposed to civilized) existence, are not only "nurturing" but also tend to manifest undesirable aspects of nature: "erratic" and therefore "dangerous" (Merchant, 1980; Schott, 1988). Such language-found throughout the rhetoric of Hoover Dam and the Colorado River-continues to be reproduced, as in Vilander's (1999) recent examination of Hoover Dam photographs, which describes the original motivation for the dam in these terms: "to control the radically waxing and waning flow of water in the Colorado River" (p. xv). In this case, not only are irregularity and unpredictability associated with the river, the chosen metaphor is 
a feminine one: the movement (flow) of the phases of the moon. Luce Irigaray (1985) and Katherine Hayles (1992) have demonstrated how masculinity, reason, and order are linked to notions of solidity while femininity, emotion, and chaos are linked to fluidity. The free-flowing river-nurturing of life but also erratic and often dangerous - thus fits well with patriarchal notions of undeveloped nature.

\section{History as Continuous Progress}

The simultaneous worship of water and demonization of the wild river is not the only argument provided to justify the building of the dam. In this second segment, we hear from a cast of historical characters-ostensibly to provide a comprehensive history of the region, but more importantly to place the building of the dam in a coherent narrative not only of progress but of cultural tradition. The first historical figure to speak to us, previewed by a return to the "Native American" musical theme, is identified simply as "Native American." He tells us that "my ancestors knew the river." He refers to the river with female pronouns and feminine imagery such as fertility and flow. While this feminization of the river continues to be of central importance throughout the presentation, the most significant role of the "native" voice is how it establishes the "naturalness" of the building of Hoover Dam (Barthes, 1972). This native's ancestors "understood the flooding of the river and the need to nourish the new seed in the spring. ... They built earthen dams to hold back the flooding of the river and to preserve water." Given this statement, Hoover Dam can be understood enthymematically as simply the next step in a logical and natural progression that began with Native American attempts to harness the river. ${ }^{5}$ Ironically, as "we" alienate ourselves from the natural world many westerners feel drawn to Native American cultures, which are symbolically positioned as possessing that which "we" now lack, a deep connection to the earth (Churchill, 1994). To complete the cycle, the environmental credibility of the "Native American" voice is appropriated to justify the building of the mechanics of alienation.

To smooth this ideological articulation of Western and native voices, elements of the story are obscured or underplayed. In his history of the Colorado River and the western United States, Fradkin (1995) provides this account of indigenous dams:

Hoover was not the first dam on the lower river, nor, in fact, was Laguna Dam, a low diversionary structure built north of Yuma in 1909. Laguna Dam was designed to raise the level of the river just high enough to form a still pool so the water could be siphoned off into a canal for irrigation purposes. It was the first large 'Indian Weir' type of dam built by the newly established Reclamation Service. The dam was also designed to serve as a sediment trap, the thinking being that the silt would settle in the quiet water behind the dam and not clog the canal. But with the full 
weight of the Colorado River and its tremendous silt load descending on the small structure, the settling basin was filled to the lip of the dam within weeks of its completion. Its effectiveness as a sediment trap was reduced more quickly than expected; as was to be the case with Imperial Dam, just upriver from Laguna. . . . Once permanent barriers were erected across the river, silt-its uneven accumulation and need for eventual deposition off the river-would become a major problem. . . . The Indians handled the silt problem by erecting temporary brush and earth-filled weirs that were easily breached by heavy river flows, thus allowing the accumulation of silt to be washed downriver. (p. 243)

Fradkin's account (which is also, admittedly and inevitably, a selective one) appears to make clear that the native peoples operated in a way that did not significantly interfere with the cyclical process of the river. That and the more obvious differences of size, method, and material are (for the moment) sidestepped to smooth not only the narrative's flow, but the ideological appropriation-not of native voices per se, but of a Western conception of the abstracted (anonymous and tribeless) "Native."

However, while Native American efforts to dam the river are used to establish a story of continuous progress between indigenous and European cultures, it must also be made clear that native (that is, uncivilized) peoples were unable to adequately control the river and thereby make it truly productive. As the "Native American" narrator states, "life followed an untrue path. The river's seasonal rhythms changed the land, leaving old channels and carving new ones, enriching the soil in one place, starving it in another. Then the white man came." The white man is positioned in this film as saving Native Americans from turmoil-that is, the cyclical forces of nature - in their own land. As we are told by the "Native American" a few minutes later (discussed below), it was only the Mormons-not his own ancestors-who "proved it was possible to prosper, even here." The assumption is clear: The river could only be tamed by the white man, whose superiority enabled a degree of subjugation the natives were presumably unable (instead of unwilling) to enact. The natural rhythms of the river are constituted as an untruth which only Western science and rationality could set "straight." While the native dams were used a moment before to establish continuity, it is not merely continuity that is sought, but that form of continuity known as progress. Native dams "failed" insofar as they were unable to control the river. While the abstract concept of dams has been justified through geo-historical continuity, the particular way of building and managing dams improves over time.

Given the important role played by the "Native American" voice in establishing a linear story of progress, the ideology of progress and development must be briefly discussed. "Progress" relies upon ongoing development, and "development" has been defined in terms of linear, systematic production. Within the dominant Western frames of science and industrialism, "progress" and "development" are 
viewed as distinct from and superior to cyclical environmental production, which the "native" narrator describes as an "untrue path." Vandana Shiva (1989), discussing a "third world" dynamic that is highly applicable to the treatment of indigenous peoples in North America, states:

The assumptions are evident: nature is unproductive; organic agriculture based on nature's cycles of renewability spells poverty; women and tribal and peasant societies embedded in nature are similarly unproductive, not because it has been demonstrated that in cooperation they produce less goods and services for needs, but because it is assumed that "production" takes place only when mediated by technologies for commodity production, even when such technologies destroy life. A sustainable and clean river is not a productive resource in this view: it needs to be "developed" with dams in order to become so. (p. 82)

Inducing an ideology of separateness from nature in order to achieve wealth and progress cultivates an idea of power over the natural environment. Nothing left in its natural state has worth unless it is "developed" by man. Nature is a set of "resources" that will be wasted if not used efficiently. In this sense, the Bureau of Reclamation succeeded in "developing" the Colorado River. In most years, the river no longer reaches the sea, where its waters would, by definition, be "wasted" (Reisner, 1993). From our discussion of the term "development" it would stand to reason that the Native Americans were on the "right" track according to Western mentalities but that they needed a little help to make the river truly "productive." Being a people grounded in the cyclical processes of nature, they were operating outside of the ring of "progress."

At least two additional texts at the dam make the link between the building of the dam and native peoples. A large carving of Native Americans near the center of the top of the dam includes this statement: "Since primordial times, American Indian tribes and nations lifted their hands to the great spirit from the ranges and plains. We now with them in peace buildeth again a nation." The presence of this text is interesting, as it appears integrated into the dam's basic structure, a likely part of the original decoration of the dam. Nevertheless, this text can be interpreted as consistent with the appropriations involved in the "native" voice from the multimedia presentation. The energies of indigenous and European peoples are presented as a unified whole, albeit a fractured one (the "buildeth again" seemingly acknowledging the prior destruction of a nation). While the contextual forces from the 1930s to the 1960s would have operated on this text in quite different ways, in a contemporary context (formed in part by the multimedia presentation) it seems plausible that this text could serve to purge "white guilt" by briefly acknowledging past injustices but focusing strongly on the continuity and unity formed by European and native peoples. 
A set of texts that can only be seen by taking a paid tour is the terrazzo floor designs in the interior of the dam. The several large black-on-white circular patterns are clearly Native American in origin or inspiration. These symbols serve to reinforce the associations between the dam and Native Americans. As architectural historian Richard Guy Wilson explains:

They are modeled on Indian designs, Navajo pottery. Symbols that look remarkably like the modern, [the] machine, the turbine, the gears that are all in motion. It's a perfect example of reaching to the past and abstracting from that to the future. It's like a chapel in a sense-it's like the chapel of the machine age. (Stept, 1999)

Wilson's seemingly adoring comment about "abstracting from [the past] to the future" can be reread more critically. ${ }^{6}$ Those aspects of native culture-such as the practice of building earthen dams, making music from a wooden flute, or in this case a certain visual aesthetic - are abstracted-that is, alienated, incorporated, exploited - in such a way as to be made consistent with the ideology of the dam. Their meanings have been contained, channeled, harnessed, and rerouted just as the river itself has been. Invisible, of course, is any indication of the struggles of native peoples to obtain their "fair share" of the Colorado River.

Consistent with this effort to unify Native and "American," in the next segment of the presentation Spanish missionaries and gold-seekers are constructed as the true villains in the life of Southwest natives. Shortly after, the "Native American" voice returns to the storyline in which Hoover will be the culmination of a centuries-long tradition of dam-building:

But then, a new people came-white, but different, with a different spirit. ... These men did not seek our friendship but they did not abuse our hospitality. They understood the way of the river and, like my ancestors, used its waters to grow food. They proved it was possible to prosper, even here. (U.S. Department of the Interior, 1998)

The next stage in the prehistory of the dam began with Mormon settlement in the 1850s. A "Mormon Settler" tells us, "I see fertile valleys here, fed by this great river." In an interesting twist on history he says "we will have no need to fight. We will leave the Indian in peace."

Once again, the storyline works to justify the dam by placing it in a tradition of operating with the river while maximizing human benefit. Implicitly drawing from the contemporary mythology of Native Americans "being one with the land," living harmoniously with it, and hence serving as environmental role models (Torgovnick, 1996), Mormons are positioned as the inheritors of that tradition. While not discussed in the presentation, Mormons were the first Europeans to successfully develop large-scale irrigation systems in the western United 
States. Subsequently, in 1902 the U.S. government launched an irrigation program under the Bureau of Reclamation that was modeled on earlier Mormon efforts and largely run by Mormons (Reisner, 1993). Therefore, by inference, the Bureau of Reclamation takes on the environmental ethic attributed to Native Americans, enhancing its ethos and diverting questions about the environmental consequences of dams such as Hoover.

The "Native American" has positive things to say about the next figure presented in this segment as well: "And then, a special man, unlike the others, an explorer, a man of great courage, a man who spoke of great dreams." Any use of John Wesley Powell to justify the damming of the Colorado is both problematic and controversial (Else, 1997), but the Hoover Dam tourist center has the advantage of being the dominant voice in the room. Despite the argument that Powell stated from the beginning that the Colorado and other western rivers simply could not "reclaim" anything but the smallest percentage of the arid West (Reisner, 1993), the Hoover Dam presentation appropriates his voice as well, using him to emphasize that there is enough water if we just "plan carefully."

Powell is also used to give voice to two other systems of meaning present in the film. First, he speaks of using the river to "bring the land to life," thereby implying that the unsettled and undeveloped West was, in fact, without life. The contradiction between this statement and the earlier one about "the web of life to which we are inexorably bound" is perhaps overshadowed by the construction of the pre-Hoover Dam Southwest as essentially dead-as "arid" and "inhospitable." The definition of "life" operating here excludes following some natural order; that is, "life" would seem to be synonymous with "productivity"-putting natural resources to human use-and "development"- the improvement of the intrinsically inadequate natural state of things. Prior to the development of structures such as Hoover Dam, the Southwest was dead because it contributed nothing to "progress." This is consistent with the name of the Bureau of Reclamation, in which "reclamation" means irrigating arid lands (McCully, 1996).

Powell and the voices of "settlers" are also used to continue the construction of the river as something needing to be tamed. The narrator explains that Powell's

early admonitions did not discourage the rapid development of the Imperial Valley of California, nor placate the temper of the river. The Colorado continued to overflow its banks and then dwindle to a trickle, retrieving in an instant the precious gift it slowly meted out. Still, the population of the Southwest continued to grow and by the last quarter of the nineteenth century the fabric of our uniquely American way of life had claimed the desert Southwest as its own. But the Colorado was still the Colorado. (U.S. Department of the Interior, 1998)

If it is not enough to add credibility to the dam by incorporating the voices of Native Americans, Mormons, and John Wesley Powell, a democratic appeal is 
also used by presenting a dialogue between several settlers who are represented in a life-size three-dimensional display behind the translucent map. The settlers bemoan the loss of their homes, crops, and possessions to floods:

"God's wrath on that river and its fickle ways."

"Levies, earthworks, they ain't no good. We need a proper dam."

"A gigantic dam to tame that wild river."

"How are we gonna raise the money?"

"The government, they'll help, and they'll listen 'cause they got a stake in this too."

"Leave the government out of this. We can do it ourselves."

"Maybe, but they have the organization and the experience and the money. I say let's talk to them." (U.S. Department of the Interior, 1998)

The dam is presented as a populist project, supported by European-American settlers and Native Americans alike, made in response to the need to "tame" the river and bring "life" to the West. No mention of corporate beneficiaries of the dam is presented during this program.

\section{Dam Domination}

The third segment chronicles the building of the dam and brings us into contemporary times. Primarily, this segment works to put viewers in awe of technology through a constant barrage of impressive numbers regarding the amount of concrete, money, workers, and other resources needed to build the dam (a focus which is similar to the tours, pamphlets, and other exhibits). Time and again seemingly insurmountable barriers are conquered by the designers and builders of the dam and entire towns, rail lines, and factories are built nearby to support the project. As quoted in the film, at the inauguration of the dam Franklin Roosevelt said, "this is an engineering victory of the first order. Another great achievement of American resourcefulness, American skill, and American determination." Exiting to the exhibition area after the completion of the presentation, visitors can see the visual manifestation of this patriotic ideology in a photograph showing an enormous American flag draped down most of the length of the 726-foot front wall of the dam.

The ideology behind this awe is complex and grounded in systems of meaning established earlier in the presentation. In the beginning, we were told that the Colorado River was "dangerous in flood, stingy in drought, erratic in mood and timing." The "Native American" begins to refer to it as "she," and settlers discuss the need to "tame" the river. With the building of the dam, these ideologies and aspirations are manifested materially:

Amid the country's economic uncertainty, the workers in this canyon gave new life to the nation's spirit as they gave new life to the desert 
Southwest. . . . When a U.S. Senate committee endorsed the construction of Hoover Dam in 1928, its report said, "a mighty river, now a source of destruction, is to be curbed and put to work in the interest of society." And so it was. Hoover Dam brought the desert flood control, a reliable supply of water, electrical power, and more. . . . Hoover Dam and other dams along the Colorado River contain the floodwaters spawned each spring by melting snows. And from their reservoirs flows an assured and reliable water supply for water users throughout the basin. . . . Wherever the system delivers water, life flourishes. (U.S. Department of the Interior, 1998)

The means by which "life" flourishes is the subjugation of the river. "With the tunnels open and the coffer dams in place, the Colorado River had no choice but to leave its riverbed and flow through the manmade corridors." This provides a specific example of the logic of domination over the earth that pervades the official presentation of the dam. The river is not "dehumanized" to justify this dominion, but is constructed as an anthropomorphized female, a living entity that is "out of control," "fickle," "erratic," and "capricious." The river's choice was taken from her and she became the product of full-blown "progress." "She" is forced to participate in the process of (re)production against her will, which, using the quote above, could be seen as roughly isomorphic with rape.

This mentality of the dam being a great achievement, built on a foundation of power-over constructs, is evident throughout a visitor's trip to Hoover Dam and adds to the sense of pleasure and dominance in those who accept the rhetoric's hail: the subject position of "nature's master" (Althusser, 1971). The final line of the presentation comes with a swelling of victorious music: "With every touch of its coarse concrete skin, and each sparkle that dances behind its crown, Hoover Dam reminds us of the need to dream . . . and the strength of the human spirit to achieve great aspirations." What is only partially stated is that the dam represents the domination of one spirit—-the "human spirit"-over an other-thanhuman and apparently feminine one. There is a conquering at work here, in which triumph comes at the cost of another's subordination, and that cost is almost completely ignored in the entire presentation. The "strength of the human spirit" functions to leave viewers uplifted in astonishment, and perhaps also filled with righteous pride for an enemy well vanquished. The eventual return from the airconditioned interior to the over-hundred-degree heat outside, magnified by the ever-present concrete, adds a somatic dimension to this rhetoric of domination.

\section{Vision Made Real}

Aside from waiting for and taking a tour, the predominant activity at the dam is spending time outside, walking across the top of the dam and looking north to Lake Mead and south down the dam to the river flowing more than five hundred 
feet below. In addition, this is the primary activity available to those not willing or able to pay for a tour. While most of visitors' time is spent looking down the dam's front face, there are a few other points of attraction. Most activity is on the Nevada side of the dam, where paid parking, a snack and gift shop, and the visitors center are located. Across from the exhibit/tour exits and near the tour entrance (as well as the snack and gift shop) is a large area of concentrated activity including several plaques, two statues, a flagpole, and a giant star chart. This is a popular area to sit, talk, and take pictures of and with the surrounding artifacts.

Visitors walking or driving by are confronted with two very large, thirty-foottall bronze statues of humanoid figures with parallel wings stretched straight upward, each sitting on a ten-foot-high block of smooth black rock. Across the highway, one can look several hundred feet down the face of the dam; here, the statues, because of their sheer height and visual dominance of the area, make people look up even though they are at the top of the dam. We are hailed as subjects looking in awe at a magnificent accomplishment, necks craned upward until the wings seemingly disappear into the sky (Althusser, 1971). The toes of the figures are smooth, shiny, and seemingly untarnished (unlike the rest of the statues) because people touch them-the only part they can reach-worshipping at the feet of . . technology? the human spirit? The statues were called "the Winged Figures of the Republic" by their creator, J. W. Hansen. Though no information is presented at the statue site itself, Hansen is quoted as saying that they express "the immutable calm of intellectual resolution, the enormous power of trained physical strength, equally enthroned in placid triumph of scientific accomplishment" (Boulder City/Hoover Dam Museum, 1998). These themes (resolution, power, strength, triumph, accomplishment) are closely related to the pleasures offered by the official discourses of the dam, a pleasure based on the possession of power-over.

An enormous vertical rock wall rises behind the statues. It rises straight up yet remains rough; long, straight, rounded-out vertical lines are visible where holes were drilled to insert explosives-traces of the dam's construction, mute reminders that what we are seeing is not quite at home in this place. Between and behind the statues, in front of the rock wall, a flagpole flies the American flag high enough to make it appear even higher than the rock wall, where a few scrawny plants hang on near the top. "It is fitting that the flag of our country should fly here in honor of those men who, inspired by a vision of lonely lands made fruitful, conceived this great work and of those others whose genius and labor made that vision a reality." The plaque on the flagpole captures the essence of this place: vision made into reality, the symbolic made material, the desire for domination realized.

Several plaques commemorate those who built and died building the dam; the most prominent is dominated by an engraving of a man, his bottom half in water, standing in front of the dam, arms seemingly holding the world up, with agricultural bounty flourishing behind the dam: "They died to make the desert 
bloom." One side of this plaque commemorates those who died building the dam, while the other continues the theme of materializing a vision: "The United States of America will continue to remember the services of all who labored to clothe with substance the plans of those who first visioned the building of this dam."

Aside from the statue, the other dominant feature of this area is a large astronomical chart showing the positions of the stars on the day the dam was dedicated, September 30, 1935. The entire stone floor around the statues and flagpole is smooth and black, inlaid with the trajectories and positions of celestial bodies. This feature creates much curious discussion among visitors. A small inlaid guide to the chart explains its function and gives directions for interpreting the information presented in the star chart. Curiously, a large raised astrological dais stands nearby.

The dam's architecture is designed to look like a place of worship. A feeling of marking where the world was in the grand order of the universe at the time of its completion is apparent. The written description of the star chart is curiously worded as if to tell the story of the dam to future civilizations (or even alien beings) should they ever happen upon this great achievement: "When in the course of our time the composition of our world and those of other worlds in space shall be more fully known . . . for future men to see and having seen to speculate, investigate and carry on the search." The hubris seems evident, the assumption that the dam will exist far into the future, perhaps past Western civilization or even humanity as a whole. As Steinberg (1993) writes, "What was being expressed here was arrogance by design. The Hoover dam that [Wallace] Stegner and the thousands of visitors before and after him viewed was supposed to signify greatness, power, and domination. It was planned that way" (p. 402). Similarly, McCully (1996) recounts that "the builders of Hoover were advised by an architect to strip the dam of planned ornamentation in order to accentuate the visual power of its concrete colossal face" (p. 3). There is a pleasure in domination, in accepting the subjectivity the dam offers "us," its affluent beneficiaries. Even critics and opponents of the dam, such as Wallace Stegner and Marc Reisner, acknowledge the sense of awe and beauty which overwhelmed them when visiting the dam.

The sense of worship is enhanced by something more subtle. Everything in, on, and around the dam is clean and polished. Brass doors and railings, both inside and out, shine brightly with hardly a finger smudge present. In the middle of a hot day, the stainless steel water fountain in the middle of the dam looks as if no one has used it since it was last cleaned. Workers can be seen cleaning windows, railings, doors, and other fixtures.

\section{The Pleasures of Alienation and Domination}

Our clocks and our schedules, our science and technology, allow us to leap on top of the undifferentiated tempos of the biological and physical 
world. We ride herd on the periodicities of nature. We tame, harness and regiment. We brand our temporal biases onto the ancient rhythms of the universe. (Rifkin, 1987, pp. 9-10)

Western, patriarchal cultures have been attempting to dominate nature for centuries, even millennia (Rifkin, 1987). With the rise of the Industrial Revolution what has been termed "progress" has systematically altered the earth, and as Steinberg (1993) argues, "the technological conquest of nature in the $20^{\text {th }}$ century has had a scale, an arrogance, with few rivals in history" (p. 402). This conquest, as with other wars, is based on a fundamental act of objectification consisting of two key elements: separation of humans from nature (a form of alienation) and positioning nature as something needing to be tamed and put to "productive" use (a form of domination). This "divide and conquer" mentality toward nature is readily apparent in the southwestern United States with the construction of Hoover Dam, a feat viewed as one of "mankind's" greatest triumphs over nature.

One way to justify the dam and its consequences is to position the Colorado River as Other. Scientific and technological needs are placed before the needs of the earth in a progressive hierarchy based on the intertwined dualisms of self/ other, culture/nature, mind/matter, and order/chaos. Through a process of positioning the environment as Other, nature is left out of the dialogue. The justification of natural destruction follows the logic of progress. The Colorado River, as a specific manifestation of "wilderness," has been constructed as in need of mastery—ordering, controlling, regulating—by humans. By scientific and economic rationalization the river has been positioned as a lesser aspect in the web of life. Technocratic and instrumental ideologies are characterized by an ethical skepticism, deeply informed by positivism and Cartesian dualism, that refuses to accept anything natural — but especially the nonhuman — as having imminent value or worth (Barglow, 1994). Harnessing the natural flow of the river makes sense in a context in which everything is viewed as an instrumentality and nature (female/ nonhuman) in particular is "othered."

If nature is labeled with the negative dualistic functions of the feminine (e.g., natural, chaotic, unproductive), it is only "logical" that the Colorado River would need a master to be prosperous. As Gaard (1997) states, "wilderness is an Other to the Self of Western culture and the master identity" (p. 5). Such a structure of meaning offers the ability to assert one's solidity, orderliness, and discipline against the fluidity and chaos of the river. In Rifkin's metaphorical terms, the discourse of the dam hails westerners as the cowboys who will "ride herd on the periodicities of nature." Part of the ideological "payoff" for embracing the official discourse about the dam is the ability to engage in the subjectivity of masculine solidity and mastery.

The flipside of the demonization of the river, therefore, is the elevation of the identity which harnessed it. The Hoover Dam area is loaded with a feeling of supreme accomplishment. When leaving a tour of Hoover Dam visitors are to be 
left with the patriotic feeling that mankind can accomplish anything. At the end of the multimedia presentation, the music swells and a feeling of security is omnipresent. The tours are completed by exiting an elevator at the middle of the top of the dam, offering a view down the middle of its arching face with the river flowing far below. This feeling of supreme power seems to be the central appeal of the official rhetoric of the dam, and offers perhaps an important answer to Steinberg's question: Why has the control over water had such an overwhelming appeal in twentieth-century America? In these discourses, and in the western United States in particular, a series of stark contrasts function to highlight the feeling and desirability of domination: solid/fluid, order/chaos, productive/wasteful, vision/matter, and culture/nature. By separating humans from the natural world, and redefining the ideal as something other than that which exists naturally, humans strive to assume power-over.

Not only is the river constituted as an Other, a desacralized object whose only worth is its use for humans, but the construction of the (dominating) Self requires (and is inseparable with) the construction of the Other. Accepting this position of domination requires that visitors separate (alienate) themselves from that which they are getting the pleasure of having power over. In this sense, the meaning of Hoover Dam is intimately linked to the alienation from the natural world in which most westerners, including those in the southwest United States, live. The dam provides electricity for air-conditioning and water for pools, fountains, and lawns. In doing so, it allows desert-dwellers to exist in the hot, dry climate by separating them from the natural conditions that surround them. It allows them to live on land that could otherwise feed, clothe, and shelter only a fraction of its present inhabitants. In short, it creates a false consciousness with regard to the ecosystems in which people live by creating the illusion that we humans are separate and above those ecosystems - as if we are protected from "the laws of nature" (Griffin, 1990). The alienation from the natural world enabled by the dam perpetuates the illusion that we as humans are separate from nature and its feminine qualities. Without this illusion of autonomy, both the "logic" of the dam and the subject position of "nature's master" are untenable.

In rhetorical studies, it is "common sense" to hold that separation is an important ingredient in rationalizing violence. Ecofeminism echoes this general position: The more humans separate themselves from nature the easier it is to rationalize its/her destruction. However, it is not simply a matter of blatant selfinterest, anthropocentrism, and false consciousness that motivates this alienation in service of domination. There are rhetorical incentives wrapped in and articulated with subjectivities and pleasures.

As Steinberg (1993) argues, an understanding of water projects in the United States requires that we adopt a view of power as productive as well as repressive. Power operates here not only as a means to control the Colorado River, but as a means for producing a particular kind of awe and pleasure, 
offering visitors the subject position of "nature's master." In the context of Marxist analyses of mass culture, Jameson (1990) holds that "the people" must be understood as more than passive dupes who have the ideology of the ruling classes beamed into their heads. Instead, a dialectical approach must examine how utopian ideals-in this case mastery over one's environmentare raised and then channeled, not simply imposing a false consciousness but offering an exchange of sorts, and thereby some cause for optimism. In the case of the Hoover Dam rhetoric, visitors are offered the vicarious pleasure of the master subject position as an inducement to accept the destruction of the river, its canyons, and their attendant life-forms and ecosystems. As ecofeminists state, a fundamental denial of dependency (a refusal to recognize that humans too are interconnected and interdependent with nature) is a necessary step in nature's transformation into a lifeless resource or hostile entity needing to be controlled. In turning "nature" (in this case, the Colorado River) into the "Other," we not only justify its objectification; following Gilman's (1985) discussion of stereotypes, the "Other" becomes a site/symbol upon which we project those traits which we ourselves embody (or at least fear we may embody), thereby maintaining the illusion of our own goodness. The Colorado River, in this instance, is the chaotic, dangerous, destructive force that enables our sense of ourselves as ordered, safe, and productive. The immense destruction wrought—on humans and nonhumans alike-by Hoover, Glen Canyon, and other dams is thereby rewritten as "reclamation," an honorable project which reaffirms our own value and perpetuates the processes of alienation by which we are separated from the consequences of our own actions (as well as from the "complex web of life to which we are inexorably bound").

\section{Conclusion}

Our analysis of the official presentation of Hoover Dam confirmed some preconceptions and raised new dimensions. During an age in which environmental sustainability is not merely a trendy idea but a grave necessity, discussions of sustainability or environmental impact are largely absent in the official rhetoric of Hoover Dam. Despite the fact that the dam arguably altered the natural rhythms of the Southwest more than any other single event in U.S. history, the history of the dam is not presented in any significant way as a lesson in environmental stewardship. Indeed, one of our most interesting and unanticipated findings is the use of a "Native American" voice to justify the dam as another stage in a transcultural narrative of human progress. While "progress" is often naturalized by grounding it in a narrative of human continuity and advancement, we were surprised to see Native Americans, who have come to represent for many Euro-Americans a harmonious and sustainable relationship to the earth, placed in this story not as a barrier but as its seed. Hence, the official presentation of 
the dam not only avoids any explicit discussion of environmental consequences, this appropriation of a "Native American" voice may also disrupt those proenvironmental impulses audiences may have.

An ideology that promotes control over nature as the supreme human accomplishment and that presents progress and nature as both dualistic and gendered was both anticipated and readily evident. As demonstrated by our analysis, the systems of "common sense" reproduced by the texts of Hoover Dam are formed through patriarchal concepts that demonize feminine traits, perpetuate the illusion of human independence from the natural world, and further the operation of instrumental thought. Yet, as ecofeminists and many others argue, this powerful feeling of independence is not only an illusion, it endangers both the natural systems whose exploitation has been justified and the humans who are nonetheless highly interdependent with their environment.

The ideologies underlying dams are being questioned ever more vigorously, and now so are the dams themselves. While no major group appears to have seriously proposed the decommissioning of Hoover Dam, such proposals have been made with regard to Glen Canyon Dam, Hoover's younger partner at the other end of the Grand Canyon, as well as smaller dams across the western United States. As a result, the need for the dam to stand fast (or crumble, depending on one's point of view) is perhaps as important ideologically as it is materially. In the official rhetoric of Hoover Dam, the constant repetition of facts, figures, and images designed to highlight the enormous weight, size, and unquestionable stability of the dam begins to evidence some ideological fraying. The dam's material solidity is presented as prima facie evidence of its ideological solidity, and this brute materiality stands silent in the face of changes in environmental consciousness. Do statistics about the number of buckets of concrete poured to make the dam continue to be an effective response to a rising chorus of green voices?

While this study is not an attempt to prove that the rhetoric of Hoover Dam is sufficient to block resistant readings and subject positions, we have identified several barriers to such acts of ideological resistance. First, the subject position of "Master of the Colorado" offers a host of pleasures for those who accept its hail, most likely serving to reinforce the commitment of those who already embrace dominant ideologies about nature. Second, the incorporation of multiple voices (Native American, Mormon, "average settlers," and John Wesley Powell) into a singular narrative of continuous progress toward mastery over nature adds the powerful force of naturalization to this most unnatural of acts. Third, there is something about the somatic experience of visiting the dam - the heat and blinding light outside and the cool darkness within, looking in one direction at the largest reservoir in the United States and in the other at a river far below-that adds potency to the verbal messages and televisual images offered to visitors. This immediate sensory experience of the dam's enormity and solidity serves as material-symbolic proof of the reality of the conquering subject position. Finally, 
just as the dam alienates us from the climates and geographies in which we live, the dam's rhetoric reinforces our distinctiveness from the untamed natural world. This alienation not only helps the dam "make sense," it offers the possibility of taking pleasure in dominating the natural world, even in an age of growing environmental sensitivity.

\section{NOTES}

1. In addition to our analysis of detailed transcriptions and photographs of the dam site and visitors center, we have spent a combined total of about twenty-six hours at the dam during eight visits, watching and listening to what people do and say and taking detailed notes of the site itself, our reactions to it, and our observations of other visitors and staff.

2. While a historical survey of the rhetoric of Hoover Dam would undoubtedly be valuable, our focus here is not to examine the historical development of the rhetoric, but the rhetorical shaping of the history of Hoover Dam in the context of contemporary environmental ideologies. One recent contribution to the historical study of Hoover Dam rhetoric is Vilander's (1999) study of the official photographs documenting the construction of Hoover Dam.

3. Unfortunately, a full comparison of the rhetorics of Hoover and Glen Canyon dams is beyond the scope of this essay. A more exhaustive examination of the rhetoric of Glen Canyon Dam as well as a fully developed comparison between the two offers fruitful possibilities for future research.

4. Given the dam's location, most visitors are either leaving, heading toward, or taking an excursion from Las Vegas. Given the close technological, economic, geographical, and tourism-related connections between Las Vegas and Hoover Dam, it can be argued that an understanding of the meanings of Hoover Dam would be incomplete without Las Vegas. Las Vegas is a city that thrives because of many of the dams along the Colorado River which provide it with water and electricity; the roots of its present status as an entertainment supercity go back to its role as an $R \& R$ center for the workers who built Hoover Dam in the 1930s.

In particular, the first segment of the multimedia presentation has important connections to the Vegas experience, especially the city's fountains, pools, and golf courses. The musical water fountain show presented in front of the Bellagio Hotel during the period of our fieldwork, for example, articulates closely with the view of water presented in the first segment of the multimedia presentation at the visitors center: clear, clean, highly controlled, and designed for human benefit. While beyond the scope of this essay, greater understanding of the rhetoric of Hoover Dam could be developed by reading Hoover Dam and Las Vegas with and against each other in a dialogic fashion.

5. Much like an incomplete syllogism, the presentation never explicitly draws the conclusion that native peoples would have wanted a huge concrete dam. However, like Aristotle's enthymeme, the conclusion appears somewhat inevitable given the premises.

6. The process of formal/aesthetic abstraction has also been discussed by Vilander (1999) in her recent work on the photographs of Hoover Dam commissioned by the Bureau of Reclamation to document the project's viability. 


\section{References}

Althusser, L. (1971). Lenin and philosophy and other essays. New York: Monthly Review Press.

Barglow, R. (1994). The crisis of self in the age of information. New York: Routledge.

Barthes, R. (1972). Mythologies. New York: Noonday.

Berger, J. (1972). Ways of seeing. New York: Penguin.

Birkeland, J. (1995). Neutralizing gender. Environmental Ethics, 17, 443-444.

Boulder City/Hoover Dam Museum. (1998). Winged figures guard Hoover Dam. Retrieved July 2, 1998 from http:/ /www.accessnv.com/bcmha/figures.htm

Churchill, W. (1994). Indians are us? Maine: Common Courage Press.

Deegan, M. J. \& Podeschi, C. W. (2001). The ecofeminist pragmatism of Charlotte Perkins Gilman. Environmental Ethics, 23, 19-36.

DeLuca, K. M. (1999). Image politics: The new rhetoric of environmental activism. New York: Guilford Press.

Else, J. (Director). (1997). Cadillac desert. [Television Series] Based on the book by Marc Reisner. San Jose, CA: KTEH.

Farmer, J. (1999). Glen Canyon dammed: Inventing Lake Powell \& the canyon country. Tucson: University of Arizona Press.

Foucault, M. (1970). The order of things: An archeology of the human sciences. New York: Vintage.

Foucault, M. (1980). Power/Knowledge: Selected interviews and other writings 1972-1977. New York: Pantheon.

Fradkin, P. (1995). A river no more: The Colorado River and the west. Berkeley: University of California Press.

Gaard, G. (1997). Ecofeminism and wilderness. Environmental Ethics, 19, 5-24.

Gilman, S. L. (1985). Difference and pathology. Ithaca, NY: Cornell University Press.

Gramsci, A. (1971). Selections from the prison notebooks of Antonio Gramsci. New York: International Publishers.

Griffin, S. (1990). Curves along the road. In I. Diamond \& G. Orenstein (Eds.), Reweaving the world: The emergence of ecofeminism (pp. 87-99). San Francisco: Sierra Club Books.

Hayles, N. K. (1992). Gender encoding in fluid mechanics: Masculine channels and feminine flows. differences, 4(2), 16-44.

Hughes, R. (1997, Spring). The beauty of big [Special issue]. Time, 46-54.

Irigaray, L. (1985). This sex which is not one. Ithaca, NY: Cornell University Press.

Jameson, F. (1990). Signatures of the visible. New York: Routledge.

McCully, P. (1996). Silenced rivers: The ecology and politics of large dams. London: Zed.

Merchant, C. (1980). The death of nature: Women, ecology and the scientific revolution. San Francisco: Harper \& Row.

National Park Service, U.S. Department of the Interior. (2001, July 12). Glen Canyon Dam. In Glen Canyon National Recreation Area. Retrieved July 12, 2001 http:// www.nps.gov/glca/damindx.htm

Pearce, F. (1991, May 4). A dammed fine mess. New Scientist, 130, 36-39.

Plumwood, V. (1993). Feminism and the mastery of nature. New York: Routledge.

Raeburn, P., Rogers \& Schutten ms ID CRV 26504 (1999, Summer). Demonstrations of power [Special issue]. Business Week, 52-63. 
Reisner, M. (1993). Cadillac desert: The American west and its disappearing water (Rev. ed.). New York: Penguin.

Rifkin, J. (1987). Time wars. New York: Simon \& Schuster.

Schott, R. M. (1988). Cognition and eros: A critique of the Kantian paradigm. Boston: Beacon Press.

Shiva, V. (1989). Development, ecology, and women. In J. Plant (Ed.), Healing the wounds: The promise of ecofeminism (pp. 80-90). Philadelphia: New Society Publishers.

Stearney, L. M. (1994). Feminism, ecofeminism, and the maternal archetype: Motherhood as a feminine universal. Communication Quarterly, 42, 145-159.

Steinburg, T. (1993). 'That world's fair feeling': Control of water in $20^{\text {th }}$-century America. Technology \& Culture, 34, 401-409.

Stept, S. (Director). (1999). Hoover Dam: The making of a monument. (television series) In The American Experience. Boston: WGBH.

Torgovnick, M. (1996). Primitive passions. Chicago: University of Chicago Press.

U.S. Department of the Interior. (1998). Hoover Dam [Multimedia program]. Nevada: Hoover Dam Visitors Center.

U.S. Department of the Interior, Bureau of Reclamation. (1998). Hoover Dam. Retrieved July 2, 1998 from http:/ /www.hooverdam.com

Vilander, B. (1999). Hoover Dam: The photographs of Ben Glaha. Tucson: University of Arizona Press.

Warren, K. (1997). Ecofeminism: Woman, culture, nature. Indianapolis: Indiana University Press.

Williams, R. (1977). Marxism and literature. New York: Oxford University Press. 
